eCommons@AKU

Book Chapters

January 2015

\title{
Teacher education pedagogies related to preparing preservice teachers as leaders in Pakistan
}

Meher Rizvi

Aga Khan University, meher.rizvi@aku.edu

Follow this and additional works at: http://ecommons.aku.edu/book_chapters

Part of the Educational Administration and Supervision Commons, Educational Assessment, Evaluation, and Research Commons, Educational Leadership Commons, Educational Methods Commons, and the Other Teacher Education and Professional Development Commons

\section{Recommended Citation}

Rizvi, M. (2015). Teacher education pedagogies related to preparing preservice teachers as leaders in Pakistan. In L. Orland-Barak \& C. J. Craig (Eds.), International teacher education: Promising pedagogies (Part B) (Vol. 22B, pp. 7-30). Bingley: Emerald Group Publishing Limited. 


\title{
TEACHER EDUCATION PEDAGOGIES RELATED TO PREPARING PRESERVICE TEACHERS AS LEADERSIN PAKISTAN
}

\author{
Meher Rizvi
}

\begin{abstract}
$\underline{\text { ABSTRACT }}$
An analysis of traditional authoritarian preservice teacher development approaches in Pakistan demonstrates that they develop teachers as technicians who carbon copy the same authoritarian training model in their classrooms. The more contemporary approaches to teacher education with leadership development focus are mostly limited to in-service teacher education programs. The key dilemma with in-service education is that once the teachers have received higher qualification they tend to move out of the classrooms to assume management positions. What Pakistan requires is classroom teacher leaders who have the capacity to initiate and sustain school improvement. I propose the pedagogy of trans- formation, which is based on the principles of participation and emancipation suited to develop preservice teachers as active professionals who have the capacity to influence and drive improvements in their own learning and in the learning of the children. The transformation pedagogy encompasses five specific instructional strategies for nurturing teachers' leadership skills in the current preservice teacher preparation program in Pakistan. These are: encourage active involvement and delegation of authority among preservice teachers, engage preservice teachers in critical analysis and meta-cognitive tasks, building collaborative teams and professional networks among preservice teachers, providing preservice teachers with experience of working with reallife teacher leaders, and develop preservice teachers' moral and ethical
\end{abstract}


reasoning. I bring the discussion to a closure in the form of a framework which encompasses key elements of the proposed pedagogy. The framework can be adopted or adapted to give due considerations to the complexities of the contexts where it is being implemented.

Keywords: Teacher education; teacher leaders; preservice teacher preparation; pedagogy of transformation; Pakistan

\section{INTRODUCTION}

The objective of education is the development of a self reliant individual, capable of analytical and original thinking, a responsible member of his/her community and, in the present era, a global citizen. (MoE, 2009)

The development of students, as envisioned by the Ministry of Education (MoE) in Pakistan, requires committed efforts from teacher leaders who have the capacity to undertake an active role in initiating and institutionalizing appropriate teaching and learning processes. Traditionally, it was the creation of administrative positions such as heads of departments or academic positions such as subject coordinators in many schools in Pakistan (Shamim, 2006) which necessitated the development of the concept of teacher leadership. Theoretically, understanding the teacher leadership concept has grown beyond the confinement of acquiring administrative positions to empowering classroom teachers to take a more active role in school improvement (Lambert, 2003; York-Barr \& Duke, 2004). However, on a practical level, the development and exercise of teacher leadership agency has yet to gain full momentum in the Pakistani context.

In a country where teaching is still the last choice of an occupation for a person of ambition and where teachers are generally reported to be neither committed nor motivated to teach (MoE, 1998, 2009), the development of teacher leaders who can transform life in school for students to become self-reliant individuals capable of analytical and original thinking may seem like a daunting task, but it is certainly not unachievable. In fact, some teacher development programs have been effective in developing teachers' capacity to undertake leadership roles even in Pakistan's difficult context.

In this chapter, I focus on a contextually relevant and significant teacher education pedagogy related to preparing preservice teachers as leaders in Pakistan. The pedagogy has been distilled from the analysis of teacher edu- 
cation programs which have been effective in developing teachers as leaders in the Pakistani context. Though embedded in the Pakistani context, it would be quite possible to transfer the proposed pedagogy to other similar contexts. In order to explicate the importance of the proposed pedagogy, background information about Pakistan's education system and the traditional approaches to teacher education are presented. This is followed by a discussion of contemporary approaches to teacher education. When required, support from the literature is also provided. I bring the discussion to a close with a framework which encompasses key elements of the pro- posed pedagogy. The framework can be adopted or adapted to give due considerations to the complexities of other international contexts in which it is being enacted.

\section{EDUCATIONAL BACKGROUND AND THE TRADITIONAL APPROACHES TO TEACHER EDUCATION}

The creation of Pakistan on the 14th of August 1947 signified for many people freedom from oppression and ignorance. People did not realize at the time that the old line of oppressors, from whom they had secured freedom at the cost of losing many precious lives, would be quickly replaced by newly liberated influential oppressors. As has been the practice in many developing nations (Freire, 1993), the new oppressors in Pakistan also used a system of education to maintain ignorance and lethargy among the masses.

Classrooms were dominated by "all knowing" and "all controlling" teachers who were very successful in producing obedient clerks who could function in the manner suited to the ruling elites. This hegemony was most apparent in the public school systems ${ }^{1}$ which were owned and administered by the state. Meanwhile, the private school systems were of varying quality and depicted a relatively different picture with principals, teachers, students, and community taking their schools rather seriously.

The transmission mode of pedagogy in the public school system, generally characterized as rote learning and memorization of facts to be regurgitated on internal school exams, was an obvious reflection on the quality of teacher education. The newly found nation's political leaders demonstrated a keen interest in shifting the emphasis of education from colonialadministrative objectives to a professional and technical bias suiting a non- 
dependent, progressive economy (Hoodbhoy, 1998). As a result, a number of educational reform initiatives were implemented under the various policy directives and plans. Nearly, all the plans emphasized the importance of quality education and reiterated the improvement in teaching standards as one way of improving quality. Yet, improvement in terms of teacher preparation programs was only minimal.

It becomes clear from the close analysis of the educational reform initiatives implemented in the first 40 years of Pakistan's independence (from 1947 to approximately 1990) that their implementation followed the same trajectory of dominance that was used to govern the education system. In the late sixties, the MoE (1959) in Pakistan presented to the people a report of the Commission on National Education which, according to some experts, was one of the most comprehensive policy documents. The com- mission recommended a complete reorganization of the country's educational system - its structure, curriculum, teacher education methods, and examination in a systematic and planned fashion. However, efforts to introduce systematic planning into education were largely unsuccessful. Their main weaknesses were the authoritarian approaches and the lack of commitment on the part of public opinion (Hayes, 1987). While the emphasis in the education policies, which followed the commission's report, was on enhancing greater teacher participation at various levels, the successive governments continued to use the same authoritarian approach to implement policy ideals.

Traditionally, teacher development in Pakistan has followed two key pathways:

1. Preservice teacher education and

2. In-service teacher education.

During this period, the preservice pathway, with its heavy reliance on teacher education as training under government control, continued to be lamented for its poor quality and for its incapacity to develop teachers as professionals who had the capacity to initiate and sustain improvements at the school level (Hasan Aly, 2007; MoE, Policy and Planning Wing, GoP, 2009; Pre-STEP, Pakistan/USAID, 2010). All the public sector teachers were by law required to undertake preservice training ${ }^{2}$ offered by the state. This authoritarian approach to teacher preparation had little to no impact on the quality of instruction in the public schools, which by now were termed "Failing Schools" in some quarters (Hoodbhoy, 1998, p. 5). Private school systems, ${ }^{3}$ during this period, continued to grow 
stronger. Since most of the private schools had their own system of inhouse teacher development, they did not require teachers to obtain any formal preservice training. In fact, it was growing dissatisfaction with preservice teacher education that led to a number of institutions offering inservice teacher education.

\section{TOWARD THE CONTEMPORARY APPROACHES TO TEACHER EDUCATION}

The latter half of the 20th century saw the emergence of several private teacher education institutions in Pakistan. These institutions offered different teacher education programs of relatively higher quality. Some of them offered teacher education programs which could meet international standards. One of the big achievements during this period was the promotion of public-private partnerships to achieve quality education targets. Initiatives to address the implementation gaps and to enhance the implementation capacity of the education sector were undertaken through the direct involvement of the donors, the federal and the provincial governments, and the non-government organizations in the opening, management, and maintenance of educational instructions at all levels (Mahmood, Zahid, \& Muhammad, 1999). Such initiatives lessened the government's authoritarian control and promoted greater participation from the stake- holders at the different levels of educational reforms planning, implementation, and institutionalization.

Unfortunately, the approach undertaken to promote greater participation from stakeholders remained quite authoritative. Educational reformers and the donors became the new authoritative figures. Teacher development plans were prepared by the experts, and implementation strategies were also decided by the experts. Trainings were mostly conducted in places away from the schools.

The focus in most of these teacher education initiatives was on the development of teachers' pedagogical skills, pedagogical content knowledge, and knowledge of subject matters. However, heavy investment in developing teachers' competencies did not bear fruitful results. Research (Rizvi, 2003; Rizvi \& Elliott, 2007) has illustrated that top-down authoritarian approaches to teacher education left teachers bewildered, unmotivated and doubtful of their own capabilities to successfully improve teaching and learning processes. As a result, the schools, particularly the 
public schools, continued to be criticized for outdated curriculum, substandard textbooks, teaching methods based on rote learning, and poor organization (ICG, 2004; Mustafa, 2004).

According to the most recent National Education Census (NEC), there are 189 teacher training institutions in the country. Table 1 gives the sectorwise (public/private) distribution of teacher training institutions, enrollment of teacher training institutions, and the total number of teaching faculty of the institutions.

In addition, there are a number of teacher training resource centers and teacher education institutions in the country offering degree awarding graduate and post-graduate level programs of varying quality, continuous professional development programs and donor-supported government educational projects. There is also a growing realization that the training imparted in the various teacher education programs needs to be geared toward developing teachers as leaders or change agents who have the capacity to successfully lead students into the 21st century. I will be specifically referring to these initiatives when I discuss teacher education pedagogy related to preparing preservice teachers as leaders. Almost all of these pro- grams have targeted in-service teachers with experience for leadership training. Nevertheless, they offer important lessons for preparing preservice teachers as leaders in Pakistan.

Table 1. Sector-Wise Distribution of the Teacher Training Institutes.

\begin{tabular}{lclr}
\hline Sector & Teacher Training Institutes & \multicolumn{1}{c}{ Enrollment } & Teaching Faculty \\
\hline Public & $152(80 \%)$ & 0.687 million $(99 \%)$ & $3,372(92 \%)$ \\
Private & $37(20 \%)$ & 0.004 million (1\%) & $279(8 \%)$ \\
\hline
\end{tabular}

Source: MoE, AEPAM (2013). 


\section{LEADERSHIP DEVELOPMENT IN PRESERVICE TEACHER EDUCATION PROGRAM}

In April 2009, the Preservice Teacher Education Program (Pre-STEP) ${ }^{4}$ National Steering Committee directed the establishment of a national task force of eminent educators from different areas of Pakistan to undertake an analytical study of the prevailing patterns, policies, and programs of preservice preparation of teachers and to recommend viable courses and programs based on the National Professional Standards for Teachers (MoE/GoP, 2009). A rationalization study was conducted in response to this quest. The study recommended a complete overhaul of preservice teacher education by replacing the traditional certificate and degree programs which were characterized by outdated pedagogies, inadequate teaching of subject matter, lack of critical thinking, and creative teaching skills with a more advanced four-year BEd (Hons.) elementary and a two-year Associate Degree in Education (ADE) (Pre-STEP/USAID, 2010).

In 2012, the Higher Education Commission (HEC) $)^{5}$ revised the curriculum for the BEd (Hons.) elementary and ADE. In line with the standards of other professional degrees such as medicine, engineering or law, the four-year BEd (Hons.) degree intends to develop teachers as professionals who require comprehensive content knowledge and intensive professional training (HEC, 2012). In clinical models of developing teachers as professionals, emphasis is placed on the development of teachers' knowledge regarding educational issues, professional pedagogy, and subject-matter knowledge, as well as to gain adequate insight into the ground-level realities of school and classrooms through supervised field experiences/ internships in schools. There are also opportunities for prospective teachers to be involved in teaching practice, administrative tasks, and small action research projects during their internship.

The curriculum of education for BEd (Hons.) and ADE is a comprehensive document comprising course descriptions, course outcomes, learning and teaching approaches, course outlines, and topics which are required to be completed in each course. There is a shift from the traditional paper/ pencil test to writing reflective journals, classroom observations, student interviews, teaching and designing a lesson. Teaching and learning approaches for most of the courses include techniques such as group work, role play, debates, presentations, discussions, peer learning, reflection, inquiry teaching, etc.

A review of the scheme of studies/courses offered in the revised preservice teacher education BEd (Hons.) and ADE program illustrate that there 
are no courses on educational leadership or teacher leadership. There seems to be more emphasis on educational administration and management functions in the scheme of studies than on developing leadership capacities. Nevertheless, the blend of content and pedagogical courses, the sensibly conceived teacher practicum and the five Cs principles of collaboration, classroom-based, constructivism, contextual, and creativity on which curriculum development is based, appear to suggest that the revised teacher curriculum of preservice teacher education can offer opportunities to prospective teachers to emerge as educational leaders. Since the revised pre- service teacher education curriculum is still in the implementation stage in the teacher education colleges of Pakistan, it is too early to see its effects at the teacher or classroom level. A number of questions come to mind at this stage: What sort of leadership training do preservice teachers need, and, more importantly, should the development of teacher leadership be left to chance or should it be a purposeful activity?

\section{THE LEADERSHIP PREPARATION THAT PRESERVICE TEACHERS NEED AND TEACHER EDUCATION PEDAGOGY RELATEDTO PREPARING PRESERVICETEACHERS AS LEADERS}

From the analysis of traditional approaches of teacher education in Pakistan, it is clear that the authoritarian training model of teacher education developed teachers as technicians who carbon copied the same authoritarian training model in their classrooms. As a result, the targets of quality education for all could not be achieved. The more contemporary approaches to teacher education are mostly limited to in-service teacher education programs. The key dilemma with in-service education is that once the teachers have received higher qualification (with the leadership specialization in particular) they tend to move out of the classrooms to assume management positions such as school principals or heads of the departments. What Pakistan requires is classroom teacher leaders who have the capacity to initiate and sustain school improvement.

The clinical model of developing teachers as professionals proposed in the new preservice teacher education curriculum in Pakistan will be rendered ineffective unless teacher leadership agency is developed. Pakistan's educational history abounds in detailed and comprehensive documents and 
idealistic reform initiatives which were created with a lot of enthusiasm and fervor, but which did not bear the results that they intended to produce. In order for teachers to fulfill the expectations outlined in the National Professional Standards for teachers in Pakistan (MoE/GoP, 2009) teachers will have to be taught the skills of planning, decision making, and taking effective initiatives, which are the key leadership functions. Without teachers' full participation and leadership, any effort to reform education will be doomed to failure. Real change cannot be mandated, even by wellintentioned policymakers (Craig \& Ross, 2008; Lieberman \& Miller, 1999).

The question of what sort of leadership training preservice teachers require can best be inferred from these words:

\begin{abstract}
Teacher leaders serve as mentors and encourage their peers; they influence policies in their schools; they assist in improving instructional practices; and they help develop the leadership capacity and improve retention of other teachers (Katzenmeyer \& Moller, 2001). As these teacher leaders work to help others develop skills and practices, they frequently hone their own teaching skills and improve their classroom performance (Ovando, 1994 cited in Thornton, 2010). The ultimate benefit is improved practice and increased student performance for all (Katzenmeyer \& Moller, 2001). Higher student achievement, even as defined by traditional measures, increases in schools with strong teacher leaders (Lambert, 2003). Teacher leadership allows excellent teachers to impact their colleagues and the students in their classrooms, and this serves as an incentive for them to remain in the classroom. (Thornton, 2010, p. 36)
\end{abstract}

There is sufficient evidence which suggests that schools demonstrate improvement when they are led by teachers who are competent and confident and who believe that they can make change happen. A study conducted with 181 teachers from six primary schools in the Maldives illustrated a positive significant relationship between teacher leadership and school effectiveness (Ngang, Abdulla, \& Mey, 2010). Furthermore, sparse studies have investigated the concept of teacher leadership in the Pakistani context (Shamim, 2006; Mohammad, 2009; Rizvi, 2003; Rizvi \& Elliott, 2005). In short, there is practically no research which has specifically explored various pedagogies related to preparing preservice teachers as leaders.

Given the importance of teacher leadership, it would not be wise to leave development of teacher leadership to chance. Purposeful formal training is required to develop teachers as leaders. One common way of preparing pre- service teachers as leaders is to add courses in teacher leadership in the existing curriculum. However, modification to existing curriculum is often not possible as it requires policy level formalities. An alternative solution would be to add teacher leadership training into the 
existing courses with the help of specific instructional strategies.

A review of the relevant teacher development programs ${ }^{6}$ in Pakistan illustrated that teacher leadership skills in these programs were developed with the help of a number of strategies such as personal reflection, providing teachers with opportunities to undertake leadership roles both within and out- side classroom, field work requiring teachers to undertake various responsibilities, research work, independent tasks, collaborative work and projects, role plays, seminars and conferences, community work, mentoring, engaging in school development plans, curriculum planning, school visits, and conducting professional development workshops.

In light of this literature review and amid the backdrop of traditional authoritarian teacher training approach, which has failed miserably, I propose a "pedagogy of transformation" (Katzenmeyer \& Moller, 2001; Lieberman, 2011; Lieberman \& Miller, 1999; Nappi, 2014), which is based on the principles of participation and emancipation suited to develop teachers as active professionals who have the capacity to influence and drive improvements in their own learning and in the learning of the children in their care. The transformation pedagogy encompasses five specific instructional strategies for nurturing preservice teachers' leadership skills in the revised teacher preparation program in Pakistan. I will now discuss each of these instructional strategies, provide evidence of their success, and discuss practical implications for developing preservice teachers' leadership within the framework of the revised teacher education program. The five strategies are thefollowing:

1. Encourage active involvement and delegation of authority among preservice teachers.

2. Engage preservice teachers in critical analysis and meta-cognitive tasks.

3. Build collaborative teams and professional networks among preservice teachers.

4. Provide preservice teachers with experience of working with real-life teacher leaders.

5. Develop preservice teachers' moral and ethical reasoning. 


\section{ENCOURAGE ACTIVE INVOLVEMENT AND DELEGATION OF AUTHORITY AMONG PRESERVICE TEACHERS}

For preservice teachers to emerge as leaders, they need to feel involved and in authority. Research conducted in public schools in Pakistan (Rizvi, 2003; Rizvi \& Elliott, 2007) has illustrated that classroom teacher leadership was enhanced when teachers were provided with opportunities to be involved in the school improvement plans and decision making, as well as in the planning of trainings and workshops.

Teacher leadership was also enhanced when teachers had the authority to choose their teaching methods and to be in control of their classroom affairs (Rizvi, 2003). The research also illustrated that when teachers were entrusted with responsibilities to represent their school's developmental activities in different forums, such as being the subject coordinator or the project in-charge they emerged as school leaders. Teacher leadership was extended beyond the four walls of the classrooms.

The effectiveness with which teacher leaders perform their leadership roles depends on such factors as level of discretion, control over work, ability to mobilize resources, and inclusion in school decisions (Apple, 1992; Cooper \& Conley, 1991). If teachers are controlled as "factory workers," then it matters little what kind of preparation they have, what kind of preparation is available to them, or what credentials they hold. Analogously, if physicians were placed in large public bureaucracies and stripped of the authority to make decisions, the argument that "doctors are professionals" would mean little (Cooper \& Conley, 1991, p. 7).

The argument and the research evidence provided here is mainly from school settings, but it offers important lessons for faculty of the preser-vice teacher education programs. Teachers in the preservice programs need to feel that they are in control of their own learning, and that their ideas have helped a new modified unit or scheme of studies to emerge. Preservice teachers need to be engaged in processes such as review of the preprepared unit/lesson plans, designing their own tasks, course eva- luation and teaching faculty evaluation, membership in various important committees of the teacher education institutions, etc. Teachers also need to be provided greater flexibility and choice in designing their school based internships and in the selection of how their learning is assessed. 


\section{ENGAGE PRESERVICE TEACHERS IN CRITICAL ANALYSIS AND META-COGNITIVE TASKS}

Teachers in Pakistani schools generally teach in ways that they were themselves taught. In this form of pedagogy, teachers do not have opportunities to question their own beliefs and understandings about the various educational issues. According to Siddiqui (2010) one of the key stumbling block in the way of change is a visible gap between teachers' professed ideas and their actual practice. Teacher preparation programs need to provide opportunities to teachers to critically reflect upon the knowledge, skills, and strategies that they are exposed to during the training and not use them because the experts say so.

There are some success stories (Ali, 2013; Khamis \& Jawed, 2006; Safida, 2006) from the teacher leader school development projects in Pakistan. An analysis of the teacher leaders in the stories had one thing in common. They were all reflective practitioners (Schon, 1983) who viewed their schools' practices critically and strived for improvement. The teachers attributed their skills in reflection and analysis to the in-service teacher training they had received from different institutions in Pakistan. For example, in one of the stories, a teacher reported how a teacher training program provided her with various opportunities to extend her learning beyond the immediate course requirement, in preparation for new leader-ship role:

\footnotetext{
So I focused my learning not only on things I felt were relevant for 9th and 10th, the classes I was teaching, but on everyone's problems. So, I would think of various alternative solutions to their problems. Now when I am guiding my teachers, suggesting an activity or giving comment on their lesson plan, I find it easy. (Adapted from an interview reported in Shamim, 2006, p. 618)
}

In another example (Ali, 2013), specific instructional strategies in an inservice training program aimed at developing institutional capacitybuilding through development of teacher leadership. Twenty teachers were developed as lead teachers, who were responsible for leading the work of school improvement as internal change agents. The specific instructional strategies that the lead teachers were exposed to included dealing with problems in action research, maintaining a reflective diary, and field based component which helped lead teachers relate their learning to school realities and reflect on emerging issues. The program helped teacher leaders in developing a critical lens to look at the perceptions, beliefs, educational practices, and socio-cultural norms. 
The teaching and learning approaches outlined in the revised BEd (Hons.) and ADE curriculum include opportunities for teachers to reflect on their practices and experiences. If executed with care and commitment such opportunities should be able to help teachers critically analyze the various educational issues and develop deeper understanding about them.

\section{BUILDING COLLABORATIVE TEAMS AND PROFESSIONAL NETWORKS AMONG PRESERVICE TEACHERS}

Research (Rizvi, 2003; Rizvi \& Elliott, 2005, 2007) has shown that for teachers to emerge as successful leaders who can build network linkages and collaborative teams, they need to be taught the skills of working together and also need to be provided with opportunities to collaborate. Teachers from schools, which have emerged as models of collaborative learning communities, have reported that educational reformers helped to develop collaborative culture in their schools by teaching them the relevant skills, modeling the skills and then providing them opportunities to model the skills.

\footnotetext{
They taught us the ways of conducting a meeting, the ways of planning a lesson together, the ways of doing yearly planning together. During our trainings, we used to be divided in groups and we used to do different activities in groups so that we could learn to work together. (Rizvi, 2003)
}

The teachers from the same school also recounted that working together during the training sessions provided them with the support and made learning easy for them. Furthermore, it provided teachers with the opportunities to meet with new people and to learn from them. This further enhanced their confidence and improved their teaching practices.

In a study of the impact of teacher collegiality on teacher professional commitment in the public secondary schools in Pakistan, Shah and Abualrob (2012) found that teacher collegiality positively influenced teacher professional commitment, which is an essential leadership characteristic. High team spirit and group involvement motivated teachers to remain committed to their respective schools and to the teaching profession.

The collaborative cultures that Pakistani schools require need to be first developed at the preservice teacher education institutions. This can be achieved by encouraging preservice teachers to work in groups during the 
training sessions and also to present their work in groups, to hold group discussions with their colleagues, to share their problems and difficulties so that together they can work toward solving them, and to exchange lessons and teaching resources among themselves.

Preservice teacher education institutions need to play an active role in cultivating partnerships with schools, in finding like-minded professionals who could provide each other with emotional support and encouragement and learn to be more confident, in providing opportunities to engage with professionals holding diverse opinions so that teachers learn from the diversity of opinions and improve their professional knowledge and expertise.

\section{PROVIDE PRESERVICE TEACHERS WITH EXPERIENCE OF WORKING WITH REAL-LIFE TEACHER LEADERS}

Based on Vygotsky's (1962) philosophy of the "more knowledgeable other," this pedagogy connected teachers with some other more experienced teacher leaders who acted as their mentors. Faculty at the teacher education institutions need to think of creative ways of providing preservice teachers with rich experience of working with real-life teacher leaders.

Recent research (Rizvi \& Nagy, 2010) was conducted to study the effect of a mentoring program on classroom teaching practices in Pakistan. The findings reported elsewhere have illustrated that the teachers who had received training from the mentors under the mentoring program were observed performing complex and challenging teaching tasks. Their classrooms comprise children who were confident and who interacted with each other regarding both academic and non-academic matters. There is a strong likelihood that the public school teachers who mostly worked under the top-down centralized system, found the friendly horizontal mentormentee channels of communication more conducive for deep learning. Among other factors, the success of the mentoring program can be attributed to the careful selection and development of mentor-mentee relationships. The mentors were selected from among senior and experienced primary and elementary school teachers. The mentors and mentees were selected from the same context. They shared the same culture, spoke the same language, and had similar contextual knowledge. The mentors conducted periodic training for mentees, observed mentees classes and pro- 
vided feedback on regular basis.

The aforementioned research directs teacher educators' attention to a number of carefully guided procedures for providing preservice teachers with experiences of working with real-life teacher leaders or mentors. One, teacher leaders or mentors need to be carefully selected so that there is good compatibility between prospective teachers and teacher leaders. Two, teacher leaders should be able to commit time for overseeing teachers' work and providing regular feedback. Three, teachers and teacher leaders must ideally be from the same interest and specialization areas. The effectiveness of teacher-teacher leaders' relationships will depend on how the relationships are developed and how they are cultivated.

\section{DEVELOP PRESERVICE TEACHERS' MORAL AND ETHICAL REASONING}

The instructional strategy of moral and ethical reasoning encompasses the other four strategies. Whether teachers continue to collaborate and network; reflect and analyze practices for improvement; execute school improvement plans with commitment will also depend on the extent to which they understand and appreciate their own ethical and moral responsibilities in the execution of these tasks.

Pakistani schools, which have withstood the test of time, have emerged as successful model schools and have been led by principals and teachers who have demonstrated highest level of moral commitment and ethical standards. For example, in a public school in Karachi, the school principal was able to inspire teachers to face difficulties confidently in their schools by modeling hard work, ethical standards, and commitment toward her responsibilities. As this teacher reported:

\footnotetext{
When we had joined this school, the school's environment was extremely bad and we did not feel like coming to the school. Our Head encouraged us a lot that time. She used to say to us, "Don't be scared. You have to stay here. God willing, there will be a day when this school will be a very good school." Listening to our Head, we gained courage and confidence. We used to say that if our Head could come so far and courageously work, so could we. (Rizvi, 2003)
}

Teachers also began to see teaching as a moral responsibility. As one teacher pointed out: 
We realized that it was our responsibility to help children improve from the beginning. In the beginning, children did not have uniform or shoes, so we used to ask them to buy shoes and uniform and we also helped them in any way we could.

It is quite clear from the already mentioned example that deep and sustained change efforts at the school level would require teacher leaders who are morally committed toward their tasks and feel ethically responsible for the well-being of the students who have been put under their care. These examples have implications for the preservice teacher education to develop preservice teachers' ethical and moral reasoning. Zia (2007) emphasizes that the college and university years are the most important ones in which students may evaluate, form and change their attitudes, values, and opinions. She adds that the values to be inculcated in teachers need to be juxtaposed and viewed from many perspectives: the global world, contextual societal/cultural norms, religious teachings, national educational aims, student needs, and future needs. This means that the translation of National Professional Standards for teachers in Pakistan (MoE/GoP, 2009) would require careful organization of learning avenues to discourage blind indoctrination of preservice teachers by instilling a naive sense of right and wrong, but inculcates in teachers the habitual ability to critically examine moral and ethical dilemma.

A review of the revised BEd (Hons.) and ADE curriculum illustrates that there are spaces to organize such learning avenues for teachers. For example, most of the courses provide prospective teachers with spaces to reflect on their teaching practices and classroom interactions. If used constructively, these spaces can provide ideal grounds for revisiting mental blocks, questioning biases, deep thinking, and understanding principled way of working. Similarly, research projects and teaching practicum are avenues for teachers to practice moral standards and ethical principles. Teaching faculty of the teacher education colleges can play an enormously important role in discussing educational issues, and providing teachers with forums to critically review and openly share their ideas.

\section{CONCLUSION}

The world is changing fast and education systems, even in the best-run countries, find it difficult to rise to the ever-greater demands placed upon them. Ambition therefore is the order of the day everywhere. How much more so, then, in a country such as Pakistan where the education system has been underperforming disastrously for dec- 
ades. Moreover, to engage people in the difficult and demanding tasks of change in a moribund system where many of those involved have given up hope requires a bold, ambitious vision. (Barber, 2013, p. 67)

Preparing teachers as leaders is one such ambitious vision, which requires immediate execution. Transforming life in Pakistani schools is no easy task, and will require teachers who are able to exercise their personal agency to influence political and structural barriers in order to improve schools. What this signifies is that social or institutional transformation is impossible to achieve without teacher transformation happening beforehand.

One may benefit from findings of the various research studies, reported here and elsewhere, which signify that when teachers are regarded as professionals who are capable of generating change and making change hap- pen, the school improvement returns are enormous and deep. Pakistan's history abounds in mandated reform initiatives to urgent teacher education issues (Riaz, 2008) which have brought about superficial changes and have left teachers skeptical of the government's intentions (Rizvi \& Elliott, 2007). Fullan (2005) advises that centrally driven mandated reforms may be the necessary first start in particular situations, but they are not sustainable. Writers such as Day, Harris, Hadfield, Tolley, and Breseford (2000), Harris, Day, and Hadfield (2003) and Lambert (1998) have called for an examination of non-traditional perspectives on leadership. Their work advocates the centrality of teachers in the leadership endeavor and highlights the importance of teachers' perspectives on school leadership.

The five specific instructional strategies, presented in this chapter, represent purposefully designed steps which can enable preservice teachers to undergo personal transformation and emerge as leaders who have the skills and the capacity to transform life in their schools for sustainable change. This is depicted in Fig. 1.

Fig. 1 proposes a certain order of execution for each of the five instructional strategies. Developing moral and ethical reasoning among preservice teachers has been proposed as a strategy which encompasses all other strategies. Teachers may be involved in ethical and moral reasoning tasks very early on their training years. 


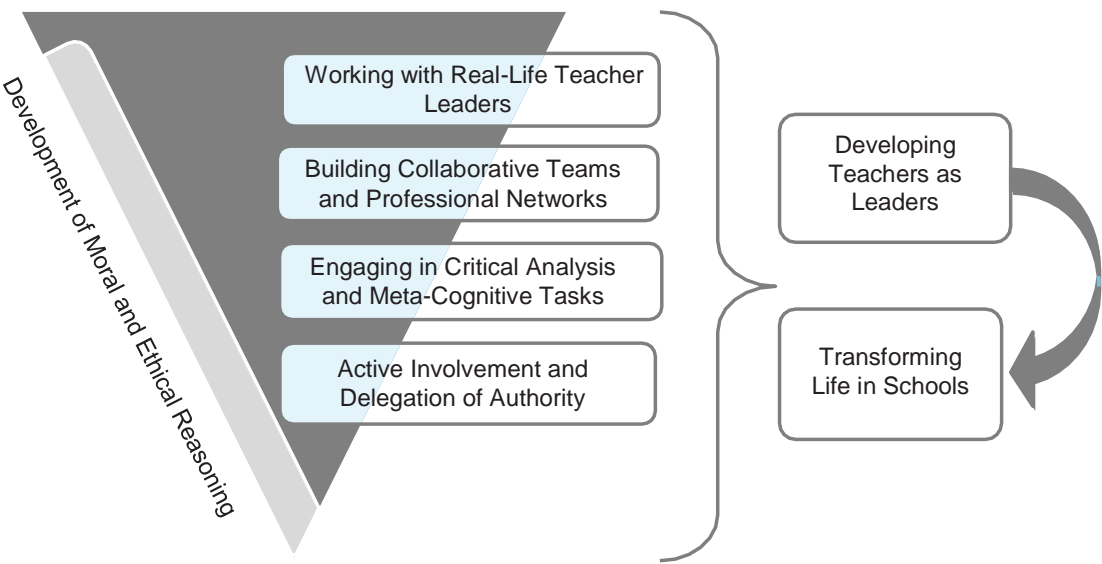

Fig. 1. Framework of Preparing Preservice Teachers as Leaders.

However, the framework proposes, that it will gain a deeper understanding as they move through the various develop- mental stages during their education.

Active involvement and delegation of authority lay the foundation of developing teachers as leaders. As the teachers engage in critical analysis and meta-cognitive tasks, they begin to view the different leadership tasks and their engagement in these tasks more critically. Development of moral and ethical reasoning combined with critical analysis prepares teachers to gain a deeper understanding about their profession and the importance of ethical execution of their role as teacher leaders.

Personal realizations regarding their roles as leaders are further strengthened and shaped when teachers are given opportunities to work collaboratively with others and build professional networks. The development of ethical and moral reasoning which began with the foundational stage by now assumes a broad base in teachers' lives. Ideally, teachers should be able to use it as a filter to shape and re-shape their beliefs when finally they are provided with the opportunities to work with successful real-life leaders in real-life situations.

The proposed framework of developing preservice teachers as leaders who are capable of transforming life in schools has emerged from my analysis of relevant research conducted in a developing world context of Pakistan. Its practical and contextual relevance can be extended to other similar contexts. Nevertheless, enactment will require judicious professional judgment. 
My professional judgment has guided me to employ the five strategies either individually or in various combinations during my career as a teacher. I also have been involved in the teaching of "School Improvement" and "Educational Change" courses to teachers and teacher educators at the graduate level. The key objectives of the courses are to help teachers under- stand and examine their roles as agents of change in school improvement and to effectively lead school improvement initiatives. Whether I am encouraging teachers to work collaboratively or engaging them in critical analysis or meta-cognitive tasks, a common thread running through the various strategies that I use is to help teachers recognize and appreciate their powers as morally committed and ethical professionals.

My research, reported earlier, on the impact of various reform initiatives to improve public schools in Pakistan has illustrated that the strategy of mentoring or working with real-life teacher leaders works quite effectively in developing leadership skills among teachers. The concept of teacher leaders in the private school systems in Pakistan differ from school to school, but it has been largely observed, particularly in large school networks, that these schools are managed by delegating authorities among the teachers and by involving them in various school-related matters. In relatively small school setups teachers tend to work by building collaborative networks. Whether teacher leaders work collaboratively or fulfill some delegated responsibilities, they must engage in some form of meta-cognitive or critical analysis tasks for the successful completion of their work. Research (Riaz, 2008; Rizvi, 2008, 2003) has illustrated that schools where reforms have sustained had one thing in common - they had committed and passionate teachers and principals who considered it their ethical and moral responsibility to help students learn and achieve.

In combining the strands to create a framework for preparing teachers as leaders, it becomes clear that the process of developing teachers as leaders needs to be viewed as a collective whole, involving all five instructional strategies. Nevertheless, a constructive message emerges, which I strongly recommend for educators and professionals who are interested in enacting this framework in their contexts. I am pointing to the developmental nature of the framework. It is quite possible to begin from any instructional strategy provided that the stage is set for it. It is also quite possible to shape the instructional strategy in a manner which is more akin to the particular con- text. On one hand, in an isolated bureaucratic culture, one would benefit by involving teachers and developing collaborative cultures which can help teachers acquire a sense of belongingness and ownership. On the other hand, in collaborative cultures, there may be possibility to 
develop professional networks, and gain a wider sense of moral purpose.

Whichever stage, teacher educators need to realize that unless teachers are developed as leaders who are able to "think," who they are capable of generating and sustaining educational change, and who "do" whatever is in their power to execute educational change, targets of quality education may remain unachievable (Fullan, 2001). The preparation of such teacher leaders requires a different more participatory and liberating teacher education approach, the transformative pedagogy, which encompasses the instructional strategies proposed in this chapter.

\section{NOTES}

1. There are three distinctive school systems in Pakistan. These are government (public) system of primary, secondary, and higher secondary schools, private school system (community, non-profit, and for-profit schools), and religious school (madrassah) system. The major problems with the quality of education in Pakistan are to be found in the public school system (ICG, 2004) that caters to three out of five school-age children.

2. Teachers obtained CT, PTC, BEd, and MEd qualifications after they had completed preservice training. The PTC teachers were under the law-qualified to teach primary classes $(\mathrm{I}-\mathrm{V})$. The basic requirement for admission to the PTC program was second division matriculation certificate or 10 years of schooling. The basic qualification for admission to CT program was higher secondary school certificate or 12 years of schooling. CT teachers were qualified to teach middle classes (VIVIII). The basic qualification for admission to BEd and MEd programs is 14 years of schooling. BEd and MEd teachers were qualified to teach in the secondary and higher secondary classes (IX-XII).

3. According to the 2006 census, out of the total teaching staff of 1,356,802 in Pakistan, 632,926 (46.6\%) were in the private sector (MoE, AEPAM, 2008).

4. Pre-STEP was a five-year program, supporting the Ministry of Education and Higher Education Commission in a comprehensive reform effort to improve the quality of preservice teacher education programs in Pakistan. The program was funded by USAID and was implemented by the Academy for Educational Development (AED). Michigan State University (MSU), and the Educational Development Centre (EDC) partnered with AED in this program.

5. The Higher Education Commission (HEC) of Pakistan is an independent, autonomous, and constitutionally established institution of primary funding, overseeing, regulating, and accrediting the higher education efforts in Pakistan.

6. These include MEd and Advanced Diploma programs offered by higher education institutions in the private sector, Whole School Improvement Program (WSIP) offered by various organizations, USAID's Education Sector Reform Assistance Program (ESRA), UNESCO's Strengthening Teacher Education Program (STEP), USAIDS' Pre-STEP, and various individual level initiatives. 


\section{REFERENCES}

Ali, T. (2013). Development of teacher leadership: A multi-faceted approach to bringing about improvements in rural elementary schools in Pakistan. Professional Development in Education. doi:10.1080/19415257.2013.828238. Retrieved from http://www.tandfonline. com/doi/pdf/10.1080/19415257.2013.828238

Apple, M. W. (1992). Teachers and texts: A political economy of class and gender relations in education. New York, NY: Routledge.

Barber, M. (2013). The good news from Pakistan. Retrieved from http://www.acasus.com/wp content/uploads/2014/02/R3-The-good-news-from-Pakistan-final.pdf

Cooper, B. S., \& Conley, S. C. (1991). From blame to empowerment: Critical issues in the tea- cher work environment. In S. C. Conley \& B. S. Cooper (Eds.), The school as a work environment: Implications for reform (pp. 2-16). Boston, MA: Allyn \& Bacon.

Craig, C., \& Ross, V. (2008). Cultivating the image of teachers as curriculum makers. In The Sage handbook of curriculum and instruction (pp. 282-305). Thousand Oaks, CA: Sage.

Day, C., Harris, A., Hadfield, M., Tolley, H., \& Breseford, J. (2000). Leading schools in times of change. Buckingham: Open University.

Freire, P. (1993). Pedagogy of the oppressed. London: Penguin Books.

Fullan, M. (2001). The new meaning of educational change. New York, NY: Teachers College.

Fullan, M. (2005). Leadership and sustainability: System thinkers in action. Thousand Oaks, CA: Corwin.

Harris, A., Day, C., \& Hadfield, M. (2003). Teachers' perspectives on effective school leader- ship. Teachers and Teaching: Theory and Practice, 9(1), 67-77.

Hasan Aly, J. (2007). Education in Pakistan: A white paper revised. Retrieved from http://planipolis.iiep.unesco.org/upload/Pakistan/Pakistan\%20National\%20Education\%20Policy \%20Review\%20WhitePaper.pdf

Hayes, L. D. (1987). The crises of education in Pakistan. Lahore: Vanguard Books.

HEC (Higher Education Commission). (2012). Curriculum of education. Retrieved from http:// www.hec.gov.pk/InsideHEC/Divisions/AECA/CurriculumRevision/Documents/Education- 2012.pdf

Hoodbhoy, P. (Ed.). (1998). Education and the state: Fifty years of Pakistan. Karachi: Oxford University.

ICG (International Crises Group). (2004). Pakistan: Reforming the education sector. Retrieved from http://www.crisisgroup.org/ /media/Files/asia/south\%20asia/pakistan/084_pakistan_reforming_the_education_sector.pdf

Katzenmeyer, M., \& Moller, G. (2001). Awakening the sleeping giant: Helping teachers develop as leaders. Thousand Oaks, CA: Corwin.

Khamis, A., \& Jawed, S. (2006). Teacher education and school improvement: A case study from Pakistan. In I. Farah \& B. Jaworski (Eds.), Partnerships in development (pp. 171-182). London: Symposium Books.

Lambert, L. (1998). Building leadership capacity in schools. Alexandria, VA: Association for Supervision and Curriculum Development.

Lambert, L. (2003). Leadership capacity for lasting school improvement. Alexandria, VA: Association for Supervision and Curriculum Development.

Lieberman, A. (2011). Can teachers really be leaders? Kappa Delta Pi Record, 48(1), 16-18. Lieberman, A., \&

Miller, L. (1999). Teachers - Transforming their world and their work. New York, NY: Teachers College.

Mahmood, N., Zahid, G. M., \& Muhammad, A. (1999). Educational development in Pakistan: Trends, issues, and policy concerns. Islamabad: Pakistan Institute of Development Economics.

MoE (Ministry of Education). (1959). National education policy: Salient features. Islamabad: GoP.

MoE (Ministry of Education). (1998). National education policy 1998-2010. Islamabad: GoP. MoE (Ministry of

Education), AEPAM (Academy of Educational Planning and Management). (2008). Pakistan education statistics 2006-07. Retrieved from http:// www.aepam.edu.pk

MoE (Ministry of Education), AEPAM (Academy of Educational Planning and Management). (2013). Annual report: Pakistan education statistics 2011-12. Retrieved from http://www.aepam.edu.pk 
MoE (Ministry of Education), GoP (Government of Pakistan). (2009). National education pol- icy 2009. Retrieved from http://planipolis.iiep.unesco.org/upload/Pakistan/Pakistan_ National_education_policy2009REV.pdf

MoE, Policy and Planning Wing, GoP. (2009). National professional standards for teachers in Pakistan. Retrieved from http://unesco.org.pk/education/teachereducation/files/ National\%20Professional\%20Standards\%20for\%20Teachers.pdf

Mohammad, A. (2009). Development of teacher leadership: A case study of a private school in Pakistan. Unpublished master's thesis. Karachi: Aga Khan University.

Mustafa, S. (2004). Analyzing failures of government initiatives in education. Dawn: Education Expo Supplement.

Nappi, J. S. (2014). The teacher leader: Improving schools by building social capital through shared leadership. The Delta Kappa Gama Bulletin, 80(4), 29-34.

Ngang, T. K., Abdulla, Z., \& Mey, S. C. (2010). Teacher leadership and school improvement in the primary schools of Maldives. H. U. Journal of Education, 39, 255-270.

Pre-STEP (Preservice Teacher Education Program) Pakistan/USAID. (2010). Rationalization of preservice teacher education programs in Pakistan. Retrieved from http://pakteachers. org/urdu/pdf/rationalization-study-report.pdf

Riaz, I. (2008). Schools for change: A perspective on school improvement in Pakistan. Improving Schools, 11(2), 143-156.

Rizvi, M. (2003). The relationships between school reforms and teacher professionalism in gov- ernment primary schools in Karachi, Pakistan. Retrieved from http://eprints.qut.edu.au/ 15955/1/Meher_Rizvi_Thesis.pdf

Rizvi, M. (2008). The role of school principal in enhancing teacher professionalism: Lessons from Pakistan. Educational Management Administration and Leadership, 36(1), 85-100.

Rizvi, M., \& Elliott, B. (2005). Teachers' perceptions of their professionalism in Government primary schools in Karachi, Pakistan. Asia-Pacific Journal of Teacher Education, 33(1), 35-52.

Rizvi, M., \& Elliott, B. (2007). Enhancing and sustaining teacher professionalism in Pakistan. Teachers and Teaching: Theory and Practice, 13(1), 5-19.

Rizvi, M., \& Nagy, P. (2010). The effects of cluster based mentoring program on teaching prac- tices in Sindh, Pakistan. Karachi: Aga Khan University.

Safida, B. (2006). A female PDT's journey in the Northern areas of Pakistan. In S. Ali \& M. Rizvi (Eds.), Quality in education: Teaching and leadership in challenging times (pp. 97-113). Karachi: AKU-IED.

Scho n, D. A. (1983). The reflective practitioner: How professionals think in action. New York, NY: Basic Books.

Shah, M., \& Abualrob, M. M. A. (2012). Teacher collegiality and teacher professional com- mitment in public secondary schools in Islamabad, Pakistan. Procedia - Social and Behavioral Sciences, 46, 950-954.

Shamim, F. (2006). Emerging roles and relationships of teacher leaders for school improve- ment in Pakistan: A case study. In S. Ali \& M. Rizvi (Eds.), Quality in education: Teaching and leadership in challenging times (pp. 614-627). Karachi: AKU-IED.

Siddiqui, S. (2010). Rethinking education in Pakistan: Perceptions, practices, and possibilities. Karachi: Paramount.

Thornton, H. J. (2010). Excellent teachers leading the way: How to cultivate teacher leader- ship. Middle School Journal, 41(4), 36-43.

Vygotsky, L. S. (1962). Thought and language. Cambridge, MA: MIT Press.

York-Barr, J., \& Duke, K. (2004). What do we know about teacher leadership? Findings from two decades of scholarship. Review of Educational Research, 74(3), 255-316.

Zia, R. (2007). Values, ethics and teacher education: A perspective from Pakistan. Higher Education Management and Policy, 19(3), 105-125. 